\title{
Characterisation of Zulu (Nguni) sheep using linear body measurements and some environmental factors affecting these measurements
}

\author{
N. Kunene ${ }^{1 \#}$, E.A. Nesamvuni ${ }^{1}$ and A. Fossey ${ }^{2}$ \\ ${ }^{1}$ Department of Agriculture, University of Zululand, Private bag X1001, Kwadlangezwa 3886, South Africa \\ ${ }^{2}$ Limpopo Department of Agriculture, Research \& Training Services Branch, \\ Private Bag X 9487, Polokwane 0700, South Africa \\ ${ }^{3}$ Forestry, Natural Resources and the Environment, CSIR, P.O. Box 17001, \\ Congella, Durban 4013, South Africa
}

\begin{abstract}
Data on linear body measurements (LBM) of $c a .100$ Zulu sheep raised under extensive management systems at four sites in northern KwaZulu-Natal were collected over a period of 2.5 years (October 2000 to May 2003). Data were used to quantify the live weight (LW), heart girth (HG), wither height (WH) and scrotum circumference (SC) of sheep in different age groups as well as the effects of some environmental factors on their LBM. Teeth numbers were used to estimate the age of sheep. The variation in LBM was influenced significantly by the location where an animal was raised and by its age. Mature rams that have three and four pairs of incisors had LWs of 37 and $38 \mathrm{~kg}$, HG of 79 and $80 \mathrm{~cm}$ and WH of 65 and $64 \mathrm{~cm}$, respectively. Mature ewes had LWs of 30 and $32 \mathrm{~kg}$, HG of $76 \mathrm{~cm}$ and WH of 62 and $61 \mathrm{~cm}$. Differences of $15 \mathrm{~kg}, 18 \mathrm{~kg}$ and $22 \mathrm{~kg}$ in LW among sheep with full sets of milk teeth and $28 \mathrm{~kg}, 35 \mathrm{~kg}$ and $40 \mathrm{~kg}$ among mature sheep were found between populations. The SC increased with age in mature rams (three and four pairs of incisors) and was $27 \mathrm{~cm}$ as compared to $18 \mathrm{~cm}$ for younger rams. Ear size ranged from ear buds to large ears of $9-14 \mathrm{~cm}$. However, type of ear-length was found not to have any particular influence on the variation in LBM of Zulu sheep. It was concluded that an investigation of genetic variation between the populations would be necessary to develop effective conservation and utilization programmes and strategies for the breed.
\end{abstract}

Keywords: Indigenous sheep, body measurements; scrotum circumference, extensive management

\# Corresponding author. E-mail: nkunene@pan.uzulu.ac.za

\section{Introduction}

Between 200 and 400 AD the original Nguni type of sheep migrated with Nguni people down the east coast of Africa southwards to the areas where they are presently located (Ramsey et al., 2000). They are divided into three groups according to their distribution, namely the Pedi sheep in Sekukunniland, the Swazi sheep in Swaziland and the Zulu sheep in KwaZulu-Natal (ARC-AII, 2001). Documented populations of the Zulu sheep are the flocks that have been established at the Makhathini Research Station (MRS) south of the Pongolo River Dam and at the University of Zululand (UNIZULU) near Empangeni in northern KwaZuluNatal. The numbers of the pure indigenous Nguni type are reported to be declining rapidly due to replacement by unrelated breeds (ARC-AII, 2001).

Indigenous sheep breeds are an important component of livestock agriculture, especially in some rural locations of South Africa. They are kept as a source of investment and to some extent as a source of food. The Zulu sheep are known to have excellent mothering ability, tolerance to external and internal parasites and to tick-borne diseases. They are well adapted to hot humid and hot dry bushveld climatic conditions (Ramsey et al., 2000). They are recorded to have thin or fat tails and have a coat cover consisting of either wool or hair (ARC-AII, 2001). However, not much research has been done to quantify the performance characteristics of the Nguni type of sheep. An accurate description of Nguni sheep kept under extensive management conditions would enable an accurate comparison of this breed with other sheep breeds, and conservation and improvement programmes can then be developed using such information.

Linear body measurements (LBM) can be used in assessing growth rate, feed utilisation and carcass characteristics in farm animals (Brown et al., 1973). Linear body measurements are divided into skeletal and tissue measurements (Essien \& Adesope, 2003). The height at withers is part of skeletal measurements 
whereas the heart girth is part of tissue measurements (Blackmore et al., 1958). Several authors have established that males with larger testicles have either a greater sperm production or a higher daily sperm output than those with smaller testicles, and that testicular size is a good indicator of ram fertility (Schoeman \& Combrink, 1987; Duguma et al., 2002). Venter et al. (1984) proposed that minimum scrotal circumference standards at certain ages should be known for individual breeds. The objective of this study was to phenotypically characterise Zulu sheep under extensive management conditions, using LBM, and to quantify some environmental factors affecting these measurements.

\section{Materials and Methods}

Data were collected monthly from $c a .100$ sheep in three populations of Nguni sheep and consisted of 2640 records. The sheep were from four location in KwaZulu-Natal and were kept under natural pastures grazing conditions. The parameters recorded per sheep were live weight (LW), heart girth (HG), wither height (WH) and scrotal circumference (SC). Table 1 shows the geographical location, period of data collection, number of sheep, number of records per traits and dominating grass species in these areas. The altitudes in these locations range from $60 \mathrm{~m}$ to $120 \mathrm{~m}$ above sea level with an annual rainfall ranging from $400 \mathrm{~mm}$ to above $1000 \mathrm{~mm}$. From May, 2002 until November, 2002 the flock at MRS was kept at the Owen Sithole College of Agriculture (OSCA) because of increased theft of the sheep at the MRS.

Table 1 Geographical location and conditions at the sites of data collection

\begin{tabular}{|c|c|c|c|c|}
\hline & $\begin{array}{c}\text { University of Zululand } \\
\text { (UNIZULU) }\end{array}$ & $\begin{array}{l}\text { Makhathini Research } \\
\text { Station (MRS)* }\end{array}$ & Enqutshini & $\begin{array}{l}\text { Owen Sithole College } \\
\text { of Agriculture (OSCA) }\end{array}$ \\
\hline $\begin{array}{c}\text { Geographical } \\
\text { location }\end{array}$ & $28^{0} 51^{\prime} S: 51^{0} 51^{\prime} \mathrm{E}$ & $25^{0} 27^{\prime} \mathrm{S}: 32^{0} 10^{\prime} \mathrm{E}$ & $28^{0} 37^{\prime} \mathrm{S}: 31^{0} 55^{\prime \prime} \mathrm{E}$ & $27^{0} 38$ 'S: $31^{0} 56^{\prime} \mathrm{E}$ \\
\hline $\begin{array}{l}\text { Period of data } \\
\text { collection } \\
\text { (number of } \\
\text { sheep) }\end{array}$ & $\begin{array}{l}\text { October, } 2000 \text { (30) } \\
\text { - May, } 2003 \text { (37) }\end{array}$ & $\begin{array}{l}\text { October, } 2000 \text { (31) } \\
\text { - April, } 2002(26) \\
\text { December, } 2002(37) \\
\text { - May, } 2003 \text { (45) }\end{array}$ & $\begin{array}{l}\text { October, } 2000 \text { (27) } \\
\text { - May, } 2003 \text { (43) }\end{array}$ & $\begin{array}{c}\text { May } 2002 \text { (26) } \\
\text { - November, } 2002 \text { (37) }\end{array}$ \\
\hline \multicolumn{5}{|l|}{$\begin{array}{l}\text { Number of records } \\
\text { per trait }\end{array}$} \\
\hline LW/HG/WH & 843 & 652 & 874 & 271 \\
\hline $\mathrm{SC}$ & 156 & 181 & 186 & 58 \\
\hline $\begin{array}{c}\text { Dominating grass } \\
\text { species }\end{array}$ & Hyperrhenia hirta & $\begin{array}{c}\text { Pennisetum clandestinum } \\
\text { and } \\
\text { Panicum maximum }\end{array}$ & Sporobolus species & Cynodon nlemfuensis \\
\hline Common names & Thatch grass & Kikuyu and Guinea grass & Dropseed & Star grass \\
\hline
\end{tabular}

* Flock kept at OSCA from May 2002 to November 2002

LW - live weight; HG - heart girth; WH - wither height; SC - scrotal circumference

The LBMs were taken $c a$. every 28 days using the measuring tape method as described by Fourie $e t$ al. (2002). The SC was measured as described by Schoeman \& Combrink (1987). Since no records were available at Enqutshini at the beginning of the study, age of the sheep in all three populations was estimated from incisors, as described by Gatenby (1991). Pregnancy status data were obtained through observation of body part changes, as described by Carles (1983). Least-square analysis of variance was done using the general linear model (GLM) procedure of Minitab (1998). Non-significant factors on the preliminary models such as year of data collection and some two-factor interactions of year with other fixed effects were excluded from the final models. Not all possible interactions were obtained because of spaces created by unequal subclasses. The Tukey's simultaneous test was used to separate significance of least-square means. Three models were used: 
Model I:

Where:

$$
\mathrm{Y}_{\mathrm{ijklmnopq}}=\mu+\mathrm{E}_{\mathrm{i}}+\mathrm{V}_{\mathrm{j}}+\mathrm{S}_{\mathrm{k}}+\mathrm{A}_{\mathrm{l}}+\mathrm{P}_{\mathrm{m}}+\mathrm{R}_{\mathrm{n}}+\mathrm{H}_{\mathrm{o}}+\mathrm{C}_{\mathrm{p}}+(\mathrm{VS})_{\mathrm{jk}}+(\mathrm{VA})_{\mathrm{jl}}+(\mathrm{SA})_{\mathrm{kl}}+(\mathrm{AH})_{\mathrm{lo}}+\mathrm{e}_{\mathrm{ijklmnopq}}
$$

$\mathrm{Y}_{\mathrm{ijk} k \mathrm{mnopq}}$ is the $\mathrm{q}^{\text {th }}$ record of $\mathrm{LW}$ and HG

$\mu=$ effect common to all sheep

$\mathrm{E}_{\mathrm{i}}=$ effect of $\mathrm{i}^{\text {th }}$ season $(1=$ summer, $2=$ autumn, $3=$ winter, $4=$ spring $)$

$\mathrm{V}_{\mathrm{j}}=$ effect of $\mathrm{j}^{\text {th }}$ location ( $1=$ UNIZULU, $2=$ Enqutshini , $3=$ Makhathini and $4=$ Owen Sithole College $)$

$\mathrm{S}_{\mathrm{k}}=$ effect of $\mathrm{k}^{\text {th }} \operatorname{sex}(1=$ male and $2=$ female $)$

$\mathrm{A}_{\mathrm{l}}=$ effect of $\mathrm{l}^{\text {th }}$ age $(1=$ milk set ( $<15$ months), $2=1$ pair of permanent incisors (15 to 22 months), $3=2$ pairs of permanent incisors ( 22 to 28 months), $4=3$ pairs of permanent incisors (28 to 36 months) and $5=4$ pairs of permanent incisors ( $>36$ months)

$\mathrm{P}_{\mathrm{m}}=$ effect of $\mathrm{m}^{\text {th }}$ status of pregnancy $(1=$ pregnant and $2=$ non-pregnant $)$

$\mathrm{R}_{\mathrm{n}}=$ effect of $\mathrm{n}^{\text {th }}$ ear length class $(1=$ ear-buds, $2=$ small $(3-6 \mathrm{~cm}), 3=$ medium $(>6-9 \mathrm{~cm}), 4=$ large $(>9-$ $14 \mathrm{~cm})$ )

$\mathrm{H}_{\mathrm{o}}=$ effect of the $\mathrm{o}^{\text {th }}$ horn status $(1=$ horned and $2=$ polled $)$

$\mathrm{C}_{\mathrm{p}}=$ effect of $\mathrm{p}^{\text {th }}$ colour $(1=$ brown, $2=$ black and white, $3=$ brown and white, $4=$ brown, black and white patched, $5=$ black, $6=$ dark-brown, $7=$ black and brown, $8=\tan$ and $9=\tan$ and white)

$\mathrm{e}_{\mathrm{ijkmnopq}}=$ random error.

Model II:

$$
\mathrm{Y}_{\mathrm{ijklmnop}}=\mu+\mathrm{E}_{\mathrm{i}}+\mathrm{V}_{\mathrm{j}}+\mathrm{S}_{\mathrm{k}}+\mathrm{A}_{\mathrm{l}}+\mathrm{R}_{\mathrm{m}}+\mathrm{H}_{\mathrm{n}}+\mathrm{C}_{\mathrm{o}}+(\mathrm{VS})_{\mathrm{jk}}+(\mathrm{VA})_{\mathrm{il}}+(\mathrm{SA})_{\mathrm{kl}}+(\mathrm{AH})_{\mathrm{ln}}+\mathrm{e}_{\mathrm{ijklmnop}}
$$

Where $\mathrm{Y}_{\mathrm{ijklmnop}}$ is the $\mathrm{p}^{\text {th }}$ record of $\mathrm{WH}$, with all terms defined as in MODEL I except for the subscript notation.

Model III:

$$
Y_{i j k l m n}=\mu+E_{i}+A_{j}+H_{k}+C_{l}+G_{m}+(A H)_{j k}+e_{i j k l m n}
$$

Where $Y_{i j k l m n}$ is the $n^{\text {th }}$ record of SC, with all terms defined as in MODEL I except for $G_{m}=$ effect of $m^{\text {th }}$ year $(1=2000,2=2001,3=2002$ and $4=2003)$ and for the subscript notation.

\section{Results and Discussions}

Table 2 Analysis of variance for live weight (LW), heart girth (HG) and wither height (WH) of Zulu sheep

\begin{tabular}{lllll}
\hline Sources & DF & LW $(\mathrm{MS})$ & HG $(\mathrm{MS})$ & WH (MS) \\
\hline Season & 3 & $891.6^{* * *}$ & $1849.1^{* * *}$ & $292.2^{* * *}$ \\
Location & 3 & $8306.1^{* * *}$ & $2979.2^{* * *}$ & $2753.1^{* * *}$ \\
Sex & 1 & $2287.7^{* * *}$ & $588.4^{* *}$ & $267.0^{* *}$ \\
Age & 4 & $11318.4^{* * *}$ & $11277.9^{* * *}$ & $4586.0^{* * *}$ \\
Status & 1 & $1996.3^{* * *}$ & $2716.1^{* * *}$ & $707.8^{* * *}$ \\
Ear & 3 & $419.8^{* * *}$ & $623.1^{* * *}$ & $349.3^{* *}$ \\
Horn & 1 & $104.3^{\mathrm{ns}}$ & $504.8^{* *}$ & $474.1^{* * *}$ \\
Colour & 8 & $309.5^{* * *}$ & $800.7^{* * *}$ & $836.6^{* * *}$ \\
Location * sex & 3 & $1200.3^{* * *}$ & $998.2^{* * *}$ & $72.0^{*}$ \\
Location * age & 12 & $144.1^{* * *}$ & $103.4^{*}$ & $224.1^{* * *}$ \\
Sex ${ }^{*}$ age & 4 & $798.9^{* * *}$ & $542.4^{* * *}$ & $520.1^{* * *}$ \\
Age ${ }^{*}$ horn & 4 & $448.0^{* * *}$ & $1192.2^{* * *}$ & 0.50
\end{tabular}

DF - degrees of freedom; MS - mean squares

$* \mathrm{P}<0.05 ; * * \mathrm{P}<0.01 ; * * * \mathrm{P}<0.001 ;$ ns - non-significant 
The analysis of variance for LW, HG and WH of sheep is presented in Table 2. The least-square means and standard errors are presented in Tables 3, 4 and 5. The models used to describe Zulu sheep accounted for $60 \%, 57 \%$ and $50 \%$ of the variation in LW, $\mathrm{HG}$ and $\mathrm{WH}$, respectively.

Table 3 Least-square means and standard errors (s.e.) for live weight (LW), heart girth (HG) and wither height (WH) of Zulu sheep

\begin{tabular}{|c|c|c|c|c|c|c|c|}
\hline Source of variation & $\mathrm{N}$ & $\begin{array}{l}\text { LW } \\
\text { (kg) }\end{array}$ & s.e. & $\begin{array}{l}\text { HG } \\
(\mathrm{cm})\end{array}$ & s.e. & $\begin{array}{l}\text { WH } \\
(\mathrm{cm})\end{array}$ & s.e. \\
\hline \multicolumn{8}{|l|}{ Season: } \\
\hline Summer & 537 & $29.25^{\mathrm{a}}$ & 0.47 & $73.72^{\mathrm{a}}$ & 0.54 & $61.10^{\mathrm{a}}$ & 0.38 \\
\hline Autumn & 719 & $30.62^{\mathrm{a}}$ & 0.41 & $74.21^{\mathrm{a}}$ & 0.47 & $61.24^{\mathrm{a}}$ & 0.34 \\
\hline Winter & 727 & $28.25^{\mathrm{b}}$ & 0.41 & $72.48^{b}$ & 0.47 & $60.69^{\mathrm{a}}$ & 0.32 \\
\hline Spring & 659 & $28.04^{\mathrm{b}}$ & 0.43 & $70.31^{\mathrm{c}}$ & 0.49 & $59.72^{\mathrm{b}}$ & 0.34 \\
\hline \multicolumn{8}{|l|}{ Location: } \\
\hline UNIZULU & 843 & $22.76^{\mathrm{a}}$ & 0.44 & $68.67^{\mathrm{a}}$ & 0.50 & $58.04^{\mathrm{a}}$ & 0.34 \\
\hline Enqutshini & 874 & $28.54^{\mathrm{b}}$ & 0.50 & $72.58^{b}$ & 0.57 & $59.84^{\mathrm{b}}$ & 0.42 \\
\hline MRS & 652 & $34.28^{c}$ & 0.44 & $75.48^{c}$ & 0.51 & $64.58^{c}$ & 0.36 \\
\hline OSCA & 271 & $30.58^{\mathrm{d}}$ & 0.75 & $74.01^{\mathrm{b}}$ & 0.85 & $60.72^{\mathrm{b}}$ & 0.63 \\
\hline \multicolumn{8}{|l|}{ Sex: } \\
\hline Males & 581 & $30.88^{\mathrm{a}}$ & 0.51 & $73.62^{\mathrm{a}}$ & 0.58 & $61.30^{\mathrm{a}}$ & 0.40 \\
\hline Females & 2059 & $27.20^{\mathrm{b}}$ & 0.37 & $71.75^{b}$ & 0.42 & $60.07^{\mathrm{b}}$ & 0.31 \\
\hline Set of milk teeth & 913 & $19.14^{\mathrm{a}}$ & 0.42 & $62.13^{\mathrm{a}}$ & 0.48 & $54.03^{\mathrm{a}}$ & 0.32 \\
\hline One pair of incisors & 361 & $27.25^{b}$ & 0.57 & $72.23^{\mathrm{b}}$ & 0.65 & $60.32^{b}$ & 0.47 \\
\hline Two pairs of incisors & 302 & $30.62^{c}$ & 0.86 & $74.18^{\mathrm{b}}$ & 0.98 & $61.92^{b}$ & 0.73 \\
\hline Three pairs of incisors & 260 & $33.46^{\mathrm{d}}$ & 0.82 & $77.65^{c}$ & 0.94 & $63.51^{c}$ & 0.70 \\
\hline Four pairs of incisors & 804 & $34.72^{\mathrm{d}}$ & 0.45 & $77.22^{c}$ & 0.51 & $63.66^{c}$ & 0.36 \\
\hline Pregnant & 242 & $30.38^{\mathrm{a}}$ & 0.48 & $74.25^{\mathrm{a}}$ & 0.55 & & \\
\hline Non-pregnant & 562 & $27.70^{\mathrm{b}}$ & 0.32 & $71.12^{b}$ & 0.37 & & \\
\hline Horned & 435 & & & & & $61.41^{\mathrm{a}}$ & 0.42 \\
\hline Polled & 2205 & & & & & $59.96^{\mathrm{b}}$ & 0.28 \\
\hline \multicolumn{8}{|l|}{ Ear length type: } \\
\hline Ear buds & 187 & $28.26^{\mathrm{a}}$ & 0.61 & $72.35^{\mathrm{a}}$ & 0.70 & $59.73^{\mathrm{a}}$ & 0.51 \\
\hline Short ears & 358 & $29.25^{b}$ & 0.47 & $72.64^{\mathrm{b}}$ & 0.53 & $60.55^{\mathrm{a}}$ & 0.38 \\
\hline Medium ear length & 793 & $28.55^{\mathrm{a}}$ & 0.40 & $71.87^{\mathrm{b}}$ & 0.46 & $60.30^{\mathrm{a}}$ & 0.32 \\
\hline Long ear length & 1302 & $30.09^{\mathrm{b}}$ & 0.38 & $73.87^{b}$ & 0.43 & $62.18^{\mathrm{b}}$ & 0.30 \\
\hline \multicolumn{8}{|l|}{ Colour: } \\
\hline Brown & 501 & $29.10^{\mathrm{a}}$ & 0.45 & $72.42^{\mathrm{a}}$ & 0.51 & $60.14^{\mathrm{a}}$ & 0.36 \\
\hline Black and white & 258 & $28.93^{\mathrm{a}}$ & 0.56 & $71.10^{\mathrm{a}}$ & 0.64 & $59.39^{\mathrm{a}}$ & 0.47 \\
\hline Brown and white & 465 & $28.94^{\mathrm{a}}$ & 0.44 & $72.49^{\mathrm{a}}$ & 0.50 & $61.03^{\mathrm{a}}$ & 0.35 \\
\hline $\begin{array}{l}\text { Brown, black and } \\
\text { white patched }\end{array}$ & 159 & $28.90^{\mathrm{a}}$ & 0.66 & $73.04^{\mathrm{a}}$ & 0.75 & $61.14^{\mathrm{a}}$ & 0.55 \\
\hline Black & 176 & $26.50^{\mathrm{b}}$ & 0.63 & $68.56^{\mathrm{b}}$ & 0.72 & $57.43^{b}$ & 0.53 \\
\hline Dark-brown & 82 & $28.20^{\mathrm{a}}$ & 0.75 & $73.14^{\mathrm{a}}$ & 0.96 & $61.47^{\mathrm{a}}$ & 0.71 \\
\hline Black and brown & 426 & $30.58^{c}$ & 0.44 & $74.27^{\mathrm{a}}$ & 0.51 & $62.01^{\mathrm{a}}$ & 0.36 \\
\hline Tan & 440 & $30.04^{c}$ & 0.47 & $74.71^{\mathrm{a}}$ & 0.54 & $61.88^{\mathrm{a}}$ & 0.39 \\
\hline Tan and white & 133 & $30.06^{\mathrm{c}}$ & 0.70 & $74.41^{\mathrm{a}}$ & 0.80 & $61.70^{\mathrm{a}}$ & 0.59 \\
\hline
\end{tabular}

a,b,c,d column means with common superscripts do not differ $(\mathrm{P}<0.05)$ 
Table 4 Least-square means and standard errors (s.e.) showing effect of location $\mathrm{x}$ sex and location $\mathrm{x}$ age interactions on live weight (LW), heart girth (HG) and wither height (WH) of Zulu sheep

\begin{tabular}{|c|c|c|c|c|c|c|c|}
\hline Source of variation & $\mathrm{N}$ & $\begin{array}{l}\mathrm{LW} \\
(\mathrm{kg})\end{array}$ & s.e. & $\begin{array}{l}\mathrm{HG} \\
(\mathrm{cm})\end{array}$ & s.e. & $\begin{array}{l}\text { WH } \\
(\mathrm{cm})\end{array}$ & s.e. \\
\hline \multicolumn{8}{|l|}{ Location * sex } \\
\hline 11 & 156 & $23.90^{\mathrm{a}}$ & 0.65 & $68.59^{\mathrm{a}}$ & 0.74 & $57.98^{\mathrm{a}}$ & 0.52 \\
\hline 12 & 687 & $21.62^{b}$ & 0.43 & $68.74^{\mathrm{a}}$ & 0.50 & $58.09^{a}$ & 0.35 \\
\hline 21 & 186 & $29.98^{c}$ & 0.79 & $73.49^{c}$ & 0.90 & $60.31^{b}$ & 0.66 \\
\hline 22 & 688 & $27.09^{d}$ & 0.44 & $71.66^{\mathrm{c}}$ & 0.50 & $59.38^{a}$ & 0.38 \\
\hline 31 & 181 & $38.64^{\mathrm{e}}$ & 0.63 & $78.61^{d}$ & 0.72 & $67.28^{\mathrm{c}}$ & 0.51 \\
\hline 32 & 471 & $29.92^{c}$ & 0.50 & $72.34^{c}$ & 0.57 & $61.88^{b}$ & 0.42 \\
\hline 41 & 58 & $31.00^{\mathrm{C}}$ & 1.14 & $73.77^{c}$ & 1.30 & $59.64^{\mathrm{b}}$ & 0.97 \\
\hline 42 & 213 & $30.17^{c}$ & 0.70 & $74.25^{\mathrm{c}}$ & 0.80 & $60.94^{b}$ & 0.60 \\
\hline \multicolumn{8}{|l|}{ Location $*$ age } \\
\hline 11 & 186 & $14.49^{\mathrm{a}}$ & 0.66 & $59.08^{a}$ & 0.75 & $51.84^{\mathrm{a}}$ & 0.54 \\
\hline 12 & 140 & $20.16^{\mathrm{b}}$ & 0.83 & $67.12^{\mathrm{b}}$ & 0.95 & $55.98^{b}$ & 0.69 \\
\hline 13 & 181 & $24.32^{c}$ & 0.90 & $71.01^{\mathrm{c}}$ & 1.03 & $59.35^{c}$ & 0.76 \\
\hline 14 & 115 & $26.76^{\mathrm{d}}$ & 0.93 & $73.37^{c}$ & 1.06 & $61.27^{c}$ & 0.79 \\
\hline 15 & 221 & $28.05^{d}$ & 0.64 & $72.76^{c}$ & 0.73 & $61.76^{c}$ & 0.53 \\
\hline 21 & 354 & $18.41^{\mathrm{e}}$ & 0.49 & $61.34^{\mathrm{d}}$ & 0.56 & $52.74^{\mathrm{a}}$ & 0.38 \\
\hline 22 & 81 & $27.74^{\mathrm{d}}$ & 0.90 & $73.53^{c}$ & 1.02 & $60.71^{b}$ & 0.76 \\
\hline 23 & 54 & $29.69^{d}$ & 0.99 & $73.72^{\mathrm{C}}$ & 1.37 & $60.49^{b}$ & 1.03 \\
\hline 24 & 71 & $31.97^{d}$ & 0.87 & $76.85^{e}$ & 1.26 & $62.36^{c}$ & 0.95 \\
\hline 25 & 314 & $34.87^{f}$ & 0.59 & $77.44^{\mathrm{e}}$ & 0.68 & $62.92^{c}$ & 0.51 \\
\hline 31 & 259 & $22.44^{\mathrm{b}}$ & 0.58 & $64.41^{\mathrm{f}}$ & 0.66 & $57.52^{b}$ & 0.47 \\
\hline 32 & 90 & $32.76^{\mathrm{d}}$ & 0.81 & $74.37^{c}$ & 0.92 & $64.47^{d}$ & 0.68 \\
\hline 33 & 48 & $36.16^{f}$ & 1.01 & $77.37^{\mathrm{e}}$ & 1.27 & $65.53^{d}$ & 0.95 \\
\hline 34 & 62 & $39.76^{\mathrm{g}}$ & 0.99 & $79.95^{e}$ & 1.13 & $67.36^{\mathrm{e}}$ & 0.85 \\
\hline 35 & 193 & $40.26^{\mathrm{g}}$ & 0.63 & $81.28^{\mathrm{e}}$ & 0.72 & $68.02^{\mathrm{e}}$ & 0.53 \\
\hline 41 & 114 & $21.22^{b}$ & 0.75 & $63.68^{f}$ & 0.86 & $54.01^{b}$ & 0.63 \\
\hline 42 & 50 & $28.36^{c}$ & 0.87 & $73.91^{\mathrm{c}}$ & 1.33 & $60.13^{c}$ & 1.00 \\
\hline 43 & 19 & $32.29^{d}$ & 1.86 & $74.62^{c}$ & 2.12 & $62.30^{\mathrm{c}}$ & 1.59 \\
\hline 44 & 12 & $35.34^{\mathrm{f}}$ & 2.09 & $80.42^{\mathrm{e}}$ & 2.38 & $63.05^{c}$ & 1.80 \\
\hline 45 & 76 & $35.70^{f}$ & 0.92 & $77.41^{\mathrm{e}}$ & 1.05 & $61.95^{c}$ & 0.78 \\
\hline
\end{tabular}

a,b,c,d,e,f column means with common superscripts do not differ $(\mathrm{P}<0.05)$

Age, location and pregnancy status seemed to have been the highest $(\mathrm{P}<0.001)$ contributing factors to the variation in LBM of the Zulu sheep (Table 2). The LBM of the sheep increased with age (Table 3). These results are in line with the conclusion made by Otte et al. (1992) and Benyi (1997) that the HG, WH and LW are measurements that can be used to evaluate growth in ruminants. The LBM of the sheep with three pairs and those with four pairs of incisors were found to be similar (Table 3). The LWs for sheep with a full set of milk teeth ( $<15$ months) at Enqutshini (Table 4) were found to be $4.03 \mathrm{~kg}$ and $2.81 \mathrm{~kg}$ lower compared to the LWs of animals of similar age groups at MRS and OSCA, respectively. The young sheep ( $<15$ months) at UNIZULU were even lower in LW by $3.92 \mathrm{~kg}, 7.95 \mathrm{~kg}$ and $6.73 \mathrm{~kg}$ than young sheep at Enqutshini, Makhathini and OSCA, respectively. The highest LWs for mature Zulu sheep (three and four pairs of incisors) were $39.76 \mathrm{~kg}$ and $40.26 \mathrm{~kg}$ at MRS with HGs of 79.95 and $81.28 \mathrm{~cm}$ and WHs of 67.36 and 68.02 $\mathrm{cm}$, respectively. The lowest LWs for the mature sheep were 26.76 and $28.05 \mathrm{~kg}$ at UNIZULU with an average HG of $73 \mathrm{~cm}$ and WH of 61.27 and $61.76 \mathrm{~cm}$ for the sheep with three and four pairs of teeth, respectively. In addition, least-square means of the location $\mathrm{x}$ age interaction (Table 4) indicate that moving of sheep from MRS to OSCA resulted to a reduced LW of sheep with 1 - 4 pairs of incisors. When at MRS, the LWs of sheep with 1, 2, 3 and 4 pairs of incisors were heavier by $4.40 \mathrm{~kg}, 3.87 \mathrm{~kg}, 4.42 \mathrm{~kg}$ and $4.56 \mathrm{~kg}$, respectively than the sheep of similar ages at OSCA. These differences could imply that the animals might have been undergoing a process of adaptation to a different environment. Provenza (2003) reported that during time of adaptation, animal performance declines before it improves, and that the degree and time of 
the decline depend on the magnitude of change in environment. However, it seems as if the change of location did not affect the sheep younger than 15 months because the least-square means of their LBMs at MRS were found to be similar $(\mathrm{P}>0.05)$ to that of the same age group at OSCA.

Sex of animal and the interaction between sex and location where they were raised were found to have an effect $(\mathrm{P}<0.001)$ on the variation on the LBM of the Zulu sheep (Table 2). The least-square means of the interaction between location and sex of animal (Table 4) reflect higher differences in LBMs between males and females on sheep reared at MRS than at UNIZULU, Enqutshini and OSCA. At MRS the males were heavier by $8.72 \mathrm{~kg}$, bigger by $6.27 \mathrm{~cm}$ and higher by $5.40 \mathrm{~cm}$ in LW, HG and WH, respectively than the females in the same flock. Such differences were smaller or not significant between males and females at the other study sites. It was remarkable to note that the difference in LBM between males and females was found to be non-significant when the flock from MRS was raised at OSCA. The change of environment from MRS to OSCA had a larger impact on males than on females. The rams at OSCA had lower LW, HG and WH by $7.64 \mathrm{~kg}, 4.84 \mathrm{~cm}$ and $7.64 \mathrm{~cm}$, respectively, than the rams at MRS. However, the LBM of the females were found to be similar $(\mathrm{P}>0.05)$ in these two locations. The fact that the LBMs of dams were not affected by change of location could explain why the young sheep (full set of milk teeth) at OSCA performed similar $(\mathrm{P}>0.05)$ in terms of LBM to those of the same age group at the MRS.

The least-square means of LBM resulting from the interaction between sex and age $(\mathrm{P}<0.001)$ in Table 5 showed that there were no differences in LBM between males and females at the milk teeth stage. The differences in LW between males and females increased with the age of the animals to $3.19 \mathrm{~kg}, 3.41 \mathrm{~kg}$ and $6.90 \mathrm{~kg}$ between rams and ewes with one, two and three pairs of permanent teeth, respectively. Hassen et al. (2002) found that male and female lambs had similar weights between 30 and 90 days of age, but differed at later stages. They reported that the significance level of sex of animal on weight of indigenous Ethiopian sheep increased with age. Similar findings were reported by Blackburn \& Field (1990) on Somali Blackhead sheep.

Season was found to have an influence on the variation in LBM $(\mathrm{P}<0.001)$ (Table 2). Black sheep were found to have larger LWs and HGs in summer and autumn than in winter and spring (Table 3). However, these differences were small (1-3 kg and 1-4 cm), respectively. Hassen et al. (2002) reported a less important seasonal influence on sheep older than 150 days compared to sheep younger than 150 days. In this study it was not possible to determine the interaction between season and age of sheep because of unequal subclasses.

The least-squares means for the age $\mathrm{x}$ horn interaction (Table 5) showed that the LBMs of young horned sheep (milk teeth stage) were higher by $5.19 \mathrm{~kg}, 8.90 \mathrm{~cm}$ and $6.14 \mathrm{~cm}$ in LW, HG and WH, respectively, than those of the polled sheep. However, at older ages no differences $(P>0.05)$ in LBM were observed between horned and polled sheep. It is possible that there is a period of rapid growth of horns at this stage. Horn production utilizes energy that could have been used for meat production in the animal (Carlson, 2001). Colour was found to have a significant effect on the LBM of Zulu sheep $(\mathrm{P}<0.001)$. Black sheep were found to have a lower LBM compared to sheep of other coat colours. During the collection of data it was observed that, as black lambs grew, they gradually changed from a black to a brown or a dark brown colour. These results are in line with the report on the deerrunssheepfarm.com website of Sponeburg (undated) where a mechanism called "dark-brown" is explained. It was reported that lambs carrying the dark-brown gene are born nearly black. As they grow older their colour fades to a distinctive dark-brown. In the present study the Zulu sheep were multicoloured. The dominating colours were brown (19\%), a combination of brown and white (18\%) and black and brown (16\%). Ramsey et al. (2000) documented that among the Nguni sheep of Zululand and Swaziland the most common colour combination was brown and black, but could include white.

In the present study a large percentage (44\%) of sheep had large ears while only $7 \%$ had ear buds (Table 3). However, the ear length had no influence on LBM in the sheep (Table 3). Among males, $41 \%$ were horned while $10 \%$ of the females had horns.

The analysis of variance for SC is presented in Table 6. The least-square means and standard errors for SC are shown in Table 7. Larger SCs were observed in autumn and summer (25 and $26 \mathrm{~cm}$ ) compared to winter and spring $(23 \mathrm{~cm})$. It is possible that the seasonal fluctuation in fodder quality and quantity did have an influence on SC. Dana et al. (2000) reported a reduced SC of 10\% in animals on a low quality diet in comparison to animals on a good quality diet. They explained that this could have been caused by loss of fat from scrotal tissue of rams maintained on poor quality diets. This is based on a report by Coulter \& Kozub 
(1984) that a reduction in testicular size of Hereford and Angus bulls on a poor quality diet was caused by the loss of fat in their scrotal tissue. The rams at MRS had the highest SC $(27 \mathrm{~cm})$ and those at UNIZULU and Enqutshini the lowest $(22$ and $23 \mathrm{~cm})$. Scrotal circumference increased with age. The youngest rams with a full set of milk teeth ( $<15$ months) had the smallest SC of $18 \mathrm{~cm}$. The mature rams (three and four pairs of incisors) had the highest SC of $27 \mathrm{~cm}$, whereas the rams in age groups of one and two pairs of incisors ( $\mathrm{P}>.05)$ had a SC of $24 \mathrm{~cm}$. The least-square means for interaction between age of sheep and the presence or absence of horns (Table 7) reflected that the difference on the SC between the horned and polled rams occurred only among the young rams with a full set of milk teeth $(<15$ months). Black rams had the lowest SC compared to rams with other coat colours (Table 7).

Table 5 Least-square means and standard errors (s.e.) showing effect of sex $\mathrm{x}$ age and age $\mathrm{x}$ horn interactions on live weight (LW), heart girth (HG) and wither height (WH) of Zulu sheep

\begin{tabular}{cccccccc}
\hline Source of variation & $\mathrm{N}$ & $\mathrm{LW}(\mathrm{kg})$ & s.e & HG $(\mathrm{cm})$ & s.e. & WH $(\mathrm{cm})$ & s.e \\
\hline Sex age & & & & & & & \\
11 & 303 & $18.69^{\mathrm{a}}$ & 0.52 & $61.15^{\mathrm{a}}$ & 0.59 & $53.34^{\mathrm{a}}$ & 0.41 \\
12 & 75 & $28.85^{\mathrm{b}}$ & 0.90 & $73.32^{\mathrm{b}}$ & 1.03 & $60.72^{\mathrm{b}}$ & 0.75 \\
13 & 40 & $32.32^{\mathrm{c}}$ & 0.87 & $74.78^{\mathrm{b}}$ & 1.45 & $62.69^{\mathrm{b}}$ & 1.08 \\
14 & 49 & $36.91^{\mathrm{d}}$ & 1.16 & $79.84^{\mathrm{c}}$ & 1.33 & $65.34^{\mathrm{c}}$ & 0.99 \\
15 & 114 & $37.64^{\mathrm{d}}$ & 0.72 & $78.99^{\mathrm{c}}$ & 0.82 & $64.42^{\mathrm{c}}$ & 0.59 \\
21 & 610 & $19.60^{\mathrm{a}}$ & 0.48 & $63.10^{\mathrm{a}}$ & 0.55 & $54.71^{\mathrm{a}}$ & 0.39 \\
22 & 286 & $25.66^{\mathrm{e}}$ & 0.66 & $70.15^{\mathrm{d}}$ & 0.55 & $57.92^{\mathrm{d}}$ & 0.56 \\
23 & 262 & $28.91^{\mathrm{b}}$ & 0.93 & $73.58^{\mathrm{b}}$ & 1.06 & $61.14^{\mathrm{b}}$ & 0.79 \\
24 & 211 & $30.01^{\mathrm{b}}$ & 0.64 & $75.46^{\mathrm{b}}$ & 1.08 & $61.68^{\mathrm{b}}$ & 0.81 \\
25 & 690 & $31.80^{\mathrm{b}}$ & 0.43 & $75.45^{\mathrm{b}}$ & 0.49 & $62.91^{\mathrm{b}}$ & 0.37 \\
Age ${ }^{*}$ horn & & & & & & & \\
11 & 153 & $21.74^{\mathrm{a}}$ & 0.66 & $66.58^{\mathrm{a}}$ & 0.76 & $57.10^{\mathrm{a}}$ & 0.55 \\
12 & 760 & $16.55^{\mathrm{b}}$ & 0.39 & $57.68^{\mathrm{b}}$ & 0.44 & $50.96^{\mathrm{b}}$ & 0.28 \\
21 & 62 & $27.18^{\mathrm{c}}$ & 0.94 & $71.90^{\mathrm{c}}$ & 1.07 & $60.99^{\mathrm{c}}$ & 0.80 \\
22 & 299 & $27.33^{\mathrm{c}}$ & 0.66 & $72.57^{\mathrm{c}}$ & 0.76 & $59.66^{\mathrm{c}}$ & 0.55 \\
31 & 28 & $30.69^{\mathrm{d}}$ & 1.42 & $74.26^{\mathrm{c}}$ & 1.62 & $61.97^{\mathrm{c}}$ & 1.22 \\
32 & 274 & $30.54^{\mathrm{d}}$ & 0.85 & $74.09^{\mathrm{c}}$ & 0.97 & $61.87^{\mathrm{c}}$ & 0.72 \\
41 & 31 & $32.69^{\mathrm{e}}$ & 1.34 & $77.36^{\mathrm{d}}$ & 1.53 & $63.03^{\mathrm{d}}$ & 1.15 \\
42 & 229 & $34.23^{\mathrm{f}}$ & 0.82 & $77.94^{\mathrm{d}}$ & 0.93 & $63.99^{\mathrm{d}}$ & 0.70 \\
51 & 161 & $34.88^{\mathrm{f}}$ & 0.62 & $77.67^{\mathrm{d}}$ & 0.71 & $63.98^{\mathrm{d}}$ & 0.53 \\
52 & 642 & $34.56^{\mathrm{f}}$ & 0.50 & $76.77^{\mathrm{d}}$ & 0.57 & $63.34^{\mathrm{d}}$ & 0.41 \\
\hline
\end{tabular}

a,b,c,d column means with common superscripts do not differ $(\mathrm{P}<0.05)$

Table 6 Analysis of variance for scrotum circumference of Zulu sheep

\begin{tabular}{lcc}
\hline Source of variation & DF & MS \\
\hline Season & 3 & $265.36^{* * *}$ \\
Location & 3 & $633.95^{* * *}$ \\
Age & 4 & $1909.99^{* * *}$ \\
Horn & 1 & $103.69^{*}$ \\
Colour & 8 & $133.20^{* * *}$ \\
Year & 3 & $155.43^{* *}$ \\
Age * horn & 4 & $163.30^{* * *}$ \\
\hline
\end{tabular}

DF - degrees of freedom; MS - mean square

$* \mathrm{P}<0.05 ; * * \mathrm{P}<0.01 ; * * * \mathrm{P}<0.001$ 
Table 7 Least-square means (Lsm) and standard errors (s.e.) for scrotum circumference (SC) of Zulu sheep

\begin{tabular}{|c|c|c|c|}
\hline Source of variation & $\mathrm{N}$ & $\operatorname{Lsm}(\mathrm{cm})$ & s.e. \\
\hline \multicolumn{4}{|l|}{ Season: } \\
\hline Summer & 109 & $25.16^{\mathrm{a}}$ & 0.73 \\
\hline Autumn & 83 & $26.10^{\mathrm{a}}$ & 0.60 \\
\hline Winter & 153 & $23.12^{\mathrm{b}}$ & 0.57 \\
\hline Spring & 136 & $22.76^{\mathrm{b}}$ & 0.56 \\
\hline \multicolumn{4}{|l|}{ Location: } \\
\hline UNIZULU & 156 & $22.11^{\mathrm{b}}$ & 0.54 \\
\hline Enqutshini & 186 & $23.32^{\mathrm{a}}$ & 0.59 \\
\hline Makhathini & 181 & $27.35^{\mathrm{a}}$ & 0.58 \\
\hline Owen Sithole & 58 & $25.37^{\mathrm{b}}$ & 0.99 \\
\hline \multicolumn{4}{|l|}{ Teeth: } \\
\hline Milk set & 284 & $18.00^{\mathrm{a}}$ & 0.49 \\
\hline One pair of permanent incisors & 84 & $24.32^{\mathrm{a}}$ & 0.67 \\
\hline Two pairs of permanent incisors & 45 & $24.26^{\mathrm{b}}$ & 0.89 \\
\hline Three pairs of permanent incisors & 54 & $27.34^{\mathrm{c}}$ & 0.80 \\
\hline Four pairs of permanent incisors & 114 & $27.58^{\mathrm{c}}$ & 0.59 \\
\hline Horned & 236 & $24.85^{\mathrm{a}}$ & 0.55 \\
\hline Polled & 345 & $23.72^{b}$ & 0.51 \\
\hline \multicolumn{4}{|l|}{ Colour: } \\
\hline Brown & 90 & $24.78^{\mathrm{a}}$ & 0.69 \\
\hline Black and white & 58 & $22.36^{\mathrm{a}}$ & 0.82 \\
\hline Brown and white & 158 & $24.33^{\mathrm{a}}$ & 0.53 \\
\hline Brown, black and white & 31 & $25.39^{\mathrm{a}}$ & 1.04 \\
\hline Black & 37 & $20.49^{b}$ & 0.96 \\
\hline Dark-brown & 31 & $24.87^{\mathrm{a}}$ & 1.00 \\
\hline Black and brown & 94 & $26.11^{\mathrm{a}}$ & 0.62 \\
\hline Tan & 54 & $24.53^{\mathrm{a}}$ & 0.79 \\
\hline Tan and white & 28 & $25.69^{\mathrm{a}}$ & 1.10 \\
\hline \multicolumn{4}{|l|}{ Year: } \\
\hline 2000 & 41 & $27.32^{\mathrm{a}}$ & 1.32 \\
\hline 2001 & 239 & $24.65^{b}$ & 0.51 \\
\hline 2002 & 161 & $23.17^{b}$ & 0.57 \\
\hline 2003 & 145 & $22.62^{b}$ & 0.65 \\
\hline \multicolumn{4}{|l|}{ Age * horn: } \\
\hline 11 & 92 & $20.33^{\mathrm{a}}$ & 0.68 \\
\hline 12 & 192 & $15.67^{\mathrm{b}}$ & 0.49 \\
\hline 21 & 43 & $24.54^{\mathrm{c}}$ & 0.87 \\
\hline 22 & 41 & $23.96^{\mathrm{c}}$ & 0.90 \\
\hline 31 & 25 & $24.64^{\mathrm{c}}$ & 1.18 \\
\hline 32 & 23 & $23.89^{c}$ & 1.18 \\
\hline 41 & 25 & $27.43^{d}$ & 0.99 \\
\hline 42 & 60 & $27.25^{d}$ & 0.87 \\
\hline 51 & 54 & $27.33^{d}$ & 0.79 \\
\hline 52 & 60 & $27.82^{d}$ & 0.75 \\
\hline
\end{tabular}

a,b,c,d column means with common superscripts do not differ $(\mathrm{P}<0.05)$

\section{Conclusion}

Zulu sheep are a multi-coloured breed. The LBMs of the males are higher than those of females and the difference in LBM between males and females increased with age. The rams were more affected in terms of LW by changes in their usual environment than the ewes. The highest LW and HG for mature Zulu rams was $38 \mathrm{~kg}$ and $80 \mathrm{~cm}$, respectively, while those of the ewes were $32 \mathrm{~kg}$ and $76 \mathrm{~cm}$. A difference of up to 12 $\mathrm{kg}$ was realized between Zulu sheep of the same age in different populations. A study on genetic variation 
between and within the populations would be necessary to make conclusive statements on the findings from this study.

Further scientific research on how changes in the environment affect rams and ewes would be required to substantiate some of the observations made in this study. It can also be concluded from this study that, although the Zulu sheep have different ear length types, this characteristic is not correlated to the LBM of the sheep. The results of this study could be used as a benchmark for further studies to predict live weight using LBM as a tool for efficient measurements in rural locations. It is also envisaged that the results of this work could be used to support genetic analyses to determine variation between and within these small populations to develop an effective conservation and utilization program.

\section{Acknowledgements}

The authors wish to acknowledge the financial assistance provided by the University of Zululand for the execution of this investigation.

\section{References}

ARC-AII, 2001. The origin of the indigenous livestock of South Africa: http://www.arc.agric.za/institutes/aii/main/divisions/ animalbreedgen/reproduction/genresdep.htm\#top

Benyi, K., 1997. Estimation of live weight from chest girth in beef cattle. National African Goats. Trop. Anim. Health Prod. 29, 124-128.

Blackburn, H.D. \& Field, C.R., 1990. Performance of Somali Blackhead sheep and Galla goats in northern Kenya. Small Rumin. Res. 3, 539-549.

Blackmore, D.W., McGulliard, L.D. \& Lush, J.L., 1958. Genetic relationship between body measurements at three ages in Holstein. J. Dairy Sci. 41, 1045-1049.

Brown, J.E., Brown, C.J. \& Butts, W.T., 1973. Evaluating relationships among immature measures of size, shape and performance on beef bulls 1; principal component as measures of size and shape in young Hereford and Angus bulls. J. Anim. Sci. 36, 1010-1020.

Carles, A.B., 1983. Sheep Production in the Tropics. Oxford University Press, New York, USA.

Carlson, M., 2001. http.personal.utulsa.edu/ marc-carlson/horn/horn1.html

Coulter, G.H. \& Kozub, G.C., 1984. Testicular development, epididymal sperm reserves and seminal quality in 2-year-old Hereford and Angus bulls: Effect of two levels dietary energy. J. Anim. Sci. 59, 432-440.

Dana, N., Shenkoru, T. \& Tegegne, A., 2000. Growth rates and testicular characteristics of Ethiopian highland sheep offered chickpea haulm supplemented with incremental levels of Leucaena leucocephala leaf hay. Livest. Prod. Sci. 65, 209-217.

Duguma, G., Cloete, S.W.P., Schoeman, S.J. \& Jordaan, G.F., 2002. Genetic parameters of testicular measurements in Merino rams and the influence of scrotal circumference on total flock fertility. S. Afr. J. Anim. Sci. 32, 76-80.

Essien, A. \& Adesope, O.M., 2003. Linear body measurements of N'dama calves at 12 months in a South Western zone of Nigeria. Livest. Res. Rural Devel. (15) 4. http://www.cipav.org.co

Fourie, P.J, Neser, F.W.C., Olivier, J.J. \& Van der Westhuizen, C., 2002. Relationship between production performance, visual appraisal and body measurements of young Dorper rams. S. Afr. J. Anim. Sci. 34, 256-261.

Gatenby, R.M., 1991. Sheep: The Tropical Agriculturalist. Macmillan Education, LTD, London.

Hassen, Y., Solkner, J., Gizaw, S. \& Baumung, R., 2002. Performance of crossbred and indigenous sheep under village conditions in the cool highlands of central northern Ethiopia. Small Rumin. Res. 43, 195-202.

Minitab Inc., 1998. Minitab Reference Manual, U.S.A.

Otte, M.J., Woods, A.J. \& Abuabara, Y., 1992. Liveweight estimation of cattle by scale and tape-A method comparison study. Trop. Anim. Health Prod. 24, 109-114.

Provenza, F.D., 2003. Foraging behavior: Managing to survive in a world of change. The U.S. Department of Agriculture and Utah State University, USA.

Ramsey, K., Harris, L. \& Kotze, A., 2000. Landrace Breeds: South Africa's indigenous and locally developed farm animals. Farm Animal Conservation Trust, Pretoria. 
Schoeman, S.J. \& Combrink, G.C., 1987. Testicular development in Dorper, Dohne Merino and crossbred rams. S. Afr. J. Anim. Sci. 17, 22-26.

Sponenburg, D.P., (undated). Colour Genetics in Coopworth sheep. http://www.deerrunsheepfarm.com/genetics.html

Venter, H.A.W., Van Zyl, J.G.E. \& Tami Vasconcellos, O.A.D.R., 1984. Comparative testicular development in young beef bulls. In: Proc. $2^{\text {nd }}$ Wrld Congr. Sheep and Beef Cattle Breeding. Eds. Hofmeyr, J.H. \& Meyer, E.H.H., April 1984, Pretoria, South Africa. 